\title{
NOTES
}

\section{THE COST DEFENSE UNDER THE AGE DISCRIMINATION IN EMPLOYMENT ACT}

In 1965, several Congressmen attempted to remedy the widespread problem of age discrimination by introducing an amendment to make age a protected classification under Title VII of the Civil Rights Act of 1964.1 Rather than pass the amendment, Congress commissioned a study on the scope of the problem ${ }^{2}$ and directed the Secretary of Labor to prepare a report with specific recommendations. ${ }^{3}$ In response to the study, Congress passed the Age Discrimination in Employinent Act of 1967 (the Act). ${ }^{4}$

The Act is designed to protect persons between the ages of forty and seventy. ${ }^{5}$ The legislative history indicates that Congress determined that this group was particularly susceptible to unfounded 6 generalizations about the decline in performance that accompanies aging. Congress sought to lessen the impact of these generalizations by requiring employers to consider an individual's ability rather than his age. $^{7}$

The primcipal operative provision of the Act provides that:

(a) It shall be unlawful for an employer-

1. 42 U.S.C. $\$ \S 2000 \mathrm{e}-2000 \mathrm{e}-5$ (1976 \& Supp. IV 1980).

2. Section 715 of the Civil Rights Act of 1964 directed the Secretary of Labor to prepare a report to Congress detailing the problems of the older American workers.

3. U.S. Dep't of Labor, The Older American Worker: Age Discrimination in EMPLOYMENT (1965) [hereinafter cited as Secretary's Report].

4. 29 U.S.C. $\S \S 621-34$ (1967 \& Supp. IV 1980).

5. 29 U.S.C. $\$ 631$ (a) (Supp. IV 1980). As originally enacted, the Act protected only persons between the ages of 40 and 65 . After considerable debate over removing the upper limit altogether, Congress decided simply to extend it to 70. See, e.g., Amendments to the Age Discrimination in Employment Act of 1967: Hearings on H.R. 65 and H.R. 1115 Before the Subcomm. on Employment Opportunities of the House Comm. on Educ. and Labor, 95th Cong., Ist Sess. 8-11 (1977) [hereinafter cited as 1977 House Hearings].

6. See, e.g., id. at 25 (remarks of Rep. Royval) (studies show no correlation between chronological age and ability); id. at 35 (remarks of Rep. Hammerschmidt) (the competence, skill, productivity, and attendance of older workers equals that of younger workers).

7. This congressional intent is illustrated by the Act's statement of purpose: "It is therefore the purpose of this chapter to promote employment of older persons based on their abihity rather than age . . . " 29 U.S.C. \& 621 (b) (1976). 
(1) to fail or refuse to hire or to discharge any individual or otherwise discriminate against any individual with respect to his coinpensation, terms, conditions, or privileges of einployinent, because of such individual's age . . . 8

This language essentially mirrors that of section 2000e-2(a)(1) of the Civil Rights Act of $1964,{ }^{9}$ and many courts have used the similarities to guide their interpretation of the Act. ${ }^{10}$ Nonetheless, at least one question is unique to age discrimination cases: whether the greater cost an employer may incur by hiring or retaining an older worker is a defense to a charge of age discrimination. Because some costs are directly associated with aging, such as increased pension and benefit costs and higher wages paid to senior einployees, the cost of retaining any individual employee usually mcreases over time. Thus, if eniployers are permitted to make employment decisions based on cost, systematic discrimination against the aged could result. ${ }^{11}$

In arguing that the cost defense is valid, employers typically assert that the neutral factor of cost controls the eniploynent decision. Cost, they argue, is a "facto[r] other than age"12 inaking the action defensible under the Act. ${ }^{13}$ The reasoning of the cases that have dealt with this argument is confused and their results are contradictory. ${ }^{14}$ This coniment provides a fresh analysis of the cost-defense problem. First, the background and the objectives of the Act are exainined to demonstrate that Congress imtended to require employers to make employinent de-

8. Id. § 623(a)(1).

9. Section 2000e-2(a)(1) provides:

(a) It shall be an unlawful practice for an employer - (1) to fail or refuse to hire or to discharge any individual, or otherwise to discriminate against any mdividual with respect to his coinpensation, terms, conditions, or privileges of employinent, because of such individual's race, religion, sex, or national origin . . . 42 U.S.C. $\$ 2000 \mathrm{e}-$ 2(a)(1)(1976). For a discussion of the significance that should be attached to this similarity in language, see note 50 infra.

10. See note 50 infra.

11. For an example, see text accompanying notes 119-21 infra.

12. 29 U.S.C. \& 623(f)(1) (1976).

13. For a discussion of the various defenses available, see notes 47-50 infra and accoinpanying text.

14. See, e.g., Marshall v. Arlene Knitwear, Inc., 454 F. Supp. 715 (E.D.N.Y. 1978) (costs directly related to age may not be considered), affd in part, rev'd in part, remanded without published opinion, 608 F.2d 1369 (2d Cir. 1979); Reed v. Shell Oil Co., 14 Fair Empl. Prac. Cas. (BNA) 875 (S.D. Ohio 1977) (employer may evaluate performance and discharge least desirable employee, regardless of age), vacated and remanded without published opinion, $582 \mathrm{F.2d} 1280$ (6th Cir. 1978); LaChapelle v. Owens-Illinois, 14 Fair Empl. Prac. Cas. (BNA) 737 (N.D. Ga. 1976) (consent judgment) (employer may not maximize profits by choosing the younger employees for trainee positions); Mastie v. Great Lakes Steel Corp., 424 F. Supp. 1299 (E.D. Mich. 1976) (employer may look at individual costs as a factor in discharges); Dounelly v. Exxon Research \& Engrs Co., 12 Fair Empl. Prac. Cas. (BNA) 417 (D.N.J. 1974), affd mem, 521 F.2d 1398 (3rd Cir. 1975) (employer may consider cost relative to production in making decisions to terminate). 
cisions based solely on an individual's performance and ability. ${ }^{15}$ The comment continues with a discussion of the one cost exception expressly included in the Act, which permits an einployer to equalize payments for pensions even if older workers thereby receive a smaller return. ${ }^{16}$ This exception further illustrates that Congress intended performance to be the employinent criterion, rather than cost. Finally, the cominent examines the practical effect of the cost defense in the context of wages increased by seniority. ${ }^{17}$ The comment concludes that, subject to certain exceptions to prevent circumvention of the Act, termination based on cost is consistent with the goals of the Act only if output, rather than absolute $\operatorname{cost}^{18}$ alone, is used as an element in computing cost. ${ }^{19}$ The onus of forced retirement is thus shifted from those arbitrarily retired because they have reached a certain age to those whose performance is below that of their colleagues, whether because of the actual effects of physical aging or for other reasons. Thus, consistent with congressional intent, merit is the sole lawful criterion for employment.

\section{OBJectives OF THE ACT}

A. Impetus for the Act.

Congress intended the Act to alleviate discrimination based on arbitrary age distinctions. ${ }^{20}$ The Secretary of Labor's study found that age discrimination is primiarily the product of unfounded assumptions about the effects of aging on performance ${ }^{21}$ and a desire to reduce the

15. See text accompanying notes 20-46 infra.

16. 29 U.S.C. \& 623(f)(2) (1976 \& Supp. IV 1980). See text accompanying notes $65-85$ infra.

17. See text accompanying notes 79-82 infra.

18. In this comment, "absolute cost" will sometimes be used to refer to wages and benefits paid, and "relative cost" to refer to absolute cost adjusted to take output into account.

19. Although an exact fornula could be proposed to reflect the effect of considering performanee as an element of cost, such as performance value $=\frac{\text { output (in dollars) }}{\text { wages }}$, this comment does not depend on any particular method of computation. The crucial point is that no employer can gauge the cost of any worker without considering his performance. To illustrate, if the employer knows only that employee A is paid $\$ 50,000$ and employee B is paid $\$ 40,000$, he does not know which employee "costs" more until he considers the amount each produces. Using the formula above, if $A$ 's output is $\$ 75,000$ and B's output is $\$ 50,000$, B is more "costly" because he produces less per dollar paid.

20. 29 U.S.C. $\S 621$ (b) (1976) (stating the purposes of the Act, including a desire "to prohibit arbitrary age discrimination in employment").

21. Secretary's Report, supra note 3, at 7-9. Senator Javits remarked in Senate hearings that "[W]e must break down the wholly irrational barriers to employinent based on age alone which have been permitted to hinder the older worker in a search for employment opportunity. Age Discrimination in Employment: Hearings on S. 830 and S. 788 Before the Subcomm. on Labor of the Senate Comm. on Labor and Public Welfare, 90th Cong., 1st Sess. 28 (1967) [hereinafter cited as 1967 Senate Hearings]. 
cost of labor, ${ }^{22}$ not hostility towards the protected group. ${ }^{23}$ Senator Javits, the principal sponsor of the Act, recognized the implications of the findings of the Secretary while speaking in support of the 1977 ainendments to the Act:

[I]t is absolutely unjustifiable in this day of increasing life expectancies to permit employees to be forced into retirement solely because they have reached an arbitrarily established age. An age that fails to take account of differential aging among individuals and different effects of aging on various skills. It could waste well-developed abilities and mature judgments. ${ }^{24}$

Congress also considered medical testimony that there was no significant relationship betwcen chronological age and the decline in performance that accompanies plysiological aging. ${ }^{25}$ In 1979, when amendments to the Act were again debated, further inedical evidence was presented to Congress emphasizing the individual nature of the aging process and the unrehability of chronological age as a measure of decline in performance. ${ }^{26}$ Typical of the testimony before Congress was Dr. Stanley R. Mohler's ${ }^{27}$ explanation of the crucial distinction between chronological age and the diseases that accompany aging. ${ }^{28} \mathrm{He}$ noted that a person free of diseases could perform many years beyond any generalized chronological limits. ${ }^{29}$ Consistent with Dr. Mohler's position, Congress found that older workers are often rated more higlly than younger workers in terins of work quality, judginent, dependa-

22. See notes 33-35 infra and accompanying text.

23. E.g., 1967 Senate Hearings, supra note 21, at 6.

24. Age Discrimination in Employment Amendments of 1977: Hearings on S. 1784 Before the Subcomm. on Labor of the Senate Comm. on Human Resources, 95th Cong., 1st Sess. 15 (1977) (statement of Senator Javits) [heremafter cited as 1977 Senate Hearings on S. 1784].

25. See, eg., H.R. REP. No. 805, 90th Cong., 1st Sess. 6 reprinted in [1967] U.S. Code CoNG. \& AD. NEws 2213, 2220; Age Discrimination Bills Before the Gen. Subcomm. on Labor of the House Comm. on Educ. and Labor, 90th Cong., 1st Sess. 7 (1967).

26. E.g., Age Discrimination Against Airline Pilots: Hearings Before House Select Comm. on Aging, 96th Cong., 1st Sess. (1979) [heremafter cited as 1979 House Hearings]. In commenting on the medical data on the aging phases, Representative Wampler stated:

The Committee certainly recognizes the deterioration of certain physiological functions with age. We also recognize that the impact of these changes varies among individuals. Thus, we hope to determine the feasiblity of measuring functional capacity on an individual basis independent of the chronological age of pilots.

Id. at 3.

27. Dr. Mohler had done extensive work on aging including four years spent with the Center for Aging Research of the National Institute of Health.

28. 1979 House Hearings, supra note 26, at 70.

29. Id. at 71 . He concluded:

Across-the-board age limits that penalize persons who are free of impairing disease and who are highly skilled and qualified at their chosen vocation are remnants of ageism from a bygone era. We can and should let the healthy functioning individual who Id. wishes to continue to be productively, safely and gainfully einployed, be so . . . . 
bility, and human relations. ${ }^{30}$ Thus, the Act's stated purpose of "prohibit[ing] arbitrary age discrimination in employment" 31 reflects the congressional consensus that generalizations based on chronological age are not accurate mdicators of performance, and that mdividual ability should be the sole criterion in employment decisions. ${ }^{32}$

Congress was concerned about economically motivated age discrimination as well as discrimination based on mistaken stereotypes. ${ }^{33}$ The court in Mastie v. Great Lakes Steel Corp. ${ }^{34}$ one of the better reasoned age discrimination cases, observed:

Cost differentials in einployinent have been denominated as the real rather than imagined reasons for discrimination against the aged. Higher employinent costs inay result from increased direct compensation or benefit programs, higher training costs, and higher costs brought about by the diminished productivity of older persons resulting froin reduced ability or physical disabilities. ${ }^{35}$

If the Mastie court's observation that it costs more to employ an older worker is correct, then any prohibition agamst age discrimmation is futile if employers remain free to make employment decisions based on cost. The crucial question is whether Congress was fully aware of the problem of cost and intended to preclude employers from circumventing the goals of the Act by using the cost defense.

\section{B. Evidence of Congressional Intent with Respect to the Cost Defense Generally.}

1. The Definition of Cost. If an employer legitimiately claims that he must fire his highest paid employees to avoid bankruptcy, most people would agree that such dismissals would be warranted..$^{36}$ Since the highest paid workers are generally the oldest, ${ }^{37}$ however, these discharges would warrant close scrutiny under the Act. Close scrutiny

30. S. ReP. No. 493, 95th Cong., 1st Sess. 3 (1977).

31. 29 U.S.C. $§ 621$ (b) (1976).

32. See id.

33. See, e.g., 1967 Senate Hearings, supra note 21, at 34 (remarks of Senator Murphy) ("employer discrimination results to a great extent from employer misconceptions about the performance of older workers and the relative cost to the firm of hiring older rather than younger workers").

34. 424 F. Supp. 1299 (E.D. Mich. 1976).

35. Id. at 1317 (footnote omitted). Several studies have demonstrated the strong correlation between length of service and salary level. See, e.g., 3 MANPOWER ADMINISTRATION, DEPT. OF LABOR, THE PRE-RETIREMENT YeARS: A LONGITUDINAL STUDY OF THE LABOR MARKET EXPERIeNCE OF MEN 67-68 (1973). See generally, Suzuki, Age, Seniority and Wages, 113 Int'l LAB. Rev. 67 (1976).

36. See, e.g., Note, The Cost of Growing Old: Business Necessity and the Age Discrimination in Employment Act, 88 YALE L.J. 565, 589-90 (1979).

37. See note 35 supra. 
would reveal that the cost of wages and benefits alone is not the true measure of the cost of an employee. ${ }^{38}$ An employer cannot know what an employee "costs" unless the employee's productivity, or the value of his output, is considered with the wages and benefits the employee receives. $^{39}$ This formula allows an employer to determine his return on wages and benefits paid and to compare meaningfully the return of different employees. Although in many cases it is difficult to compare directly the output of employees, the employer who does not attempt to do so cannot recognize his most expensive employees or legitimately claim that he must discharge them.

There is considerable evidence that Congress's purpose im passing the Act was to encourage employers to base their decisions on performance. The legislative history emphasizes the need for evaluations of individual performance. ${ }^{40}$ Furthermore, Congress expressly enacted two defenses to the Act that are designed to force the employer to focus on the performance of his employees. ${ }^{41}$ Finally, in the one situation in which Congress realized that cost was unrelated to performance-that of bona fide employee benefits-it created an express exception to the Act concerning cost. ${ }^{42}$ These facts imdicate that Congress did not in-

38. See note 18 supra.

39. In Donnelly v. Exxon Research \& Eng'r Co., 12 Fair Empl. Prac. Cas. (BNA) 417 (D.N.J. 1974), affd mem, 521 F.2d 1398 (3d Cir. 1975), the court approved a plan in which performance was considered in determining cost, and the least productive einployees were terminated. The plan did not detail how the evaluation was to be made, but it apphed equally to all employees. A reaction to financial problems, the plan was designed to terminate "ineffective employees" whose decline in performance may have been attributable to "[l]ack of ability or motivation" or to "technical obsolescence or declining value to the company of his field of specialization." $I d$. at 420 (quoting company policy). For further discussion of the plan, see notes 127-32 infra and accompanying text.

40. See notes 20-35 supra and accompanying text.

41. See notes 47-64 infra and accompanying text.

42. 29 U.S.C. $\$ 623(f)(2)$ (1976 \& Supp. IV 1980). This exception is the sole express provision embodying any concept of a cost defense. Express exceptions to remedial legislation are normally deemed to be exclusive. See, e.g., Colorado Pub. Interest Research Group, Inc. v. Train, 507 F.2d 743, 747 (10th Cir. 1974) (if there are express exceptions to a statute, additional exceptions by implication are not favored), rev'd on other grounds, 426 U.S. 1 (1976). The exception was passed in response to the realization that older workers would be handicapped if they were always more expensive. See, e.g., Age Discrimination in Employment: Hearings on H.R. 3651, H.R 3768 and H.R 4221 Before the Subcomm on Labor of the House Comm. on Education and Labor, 90th Cong., Ist Sess. 70 (1967) [heremafter cited as 1967 House Hearings] (Statement of Mr. Pestillo, represeuting the U.S. Chamber of Commerce). Mr. Pestillo explained that an older worker looking for a job would be handicapped because it would cost an employer more to hire him. He behieved that "if you saddle the [older worker] with the fact that he is going to cost the employer $\$ 240$ a year [estimated differential based on pension and imsurance benefits] more than likely the employer will find another reason for not giving him employment." For a nore complete discussion of the implications of this exception, see text, section I.C. infra. 
tend cost alone to control employment decisions. Cost was intended to be only one element in evaluating performance.

2. The Unique Feature of Age Discrimination: The Permissible Classifier, Performance, Is Eventually Affected by the Forbidden Classifier, Age. If the objectives of the Act are met, an employee cannot be terminated because of his chronological age. But this is not to say that an employee cannot be terminated once he begms to show the signs of physical aging that affect performance. There are nuinerous examples in the legislative history supporting the employer's freedorn to terminate an employee whose performance has declined because of deinonstrable physical aging. ${ }^{43}$ Only in the area of age discrimination do the features of the stereotype associated with the forbidden factor, age, eventually become true for the individual. ${ }^{44}$ Because of this unique problem, the objectives of the Act should be carefully examined without undue rehance on the interpretations of other anti-discrimination statutes not designed with this problein in mind. ${ }^{45}$

In its present form, the Act reflects this feature of age discrimination. The Act requires employers to identify the point at which the performance-specific generalizations about aging become true for the individual. One corollary to this requirement is that employers wishing to take action against protected einployees inay do so only after individual performance evaluations. A congressional committee appointed to study ways of improving the Act summarized this analysis by observing that:

Clearly, no employee should remam in a position if he or she cannot meet its demands and the law recognizes this fact. But equally clearly, no employee should be forced to quit or retire early simply because of reaching a certain age. Such judgments should be made on the basis of facts, not blanket assumptions. ${ }^{46}$

3. Ability-Related Defenses Under the Act. The Act permits an employer to discriminate based on age if "age is a bona fide occupational qualification reasonably necessary to the normal operation of the

43. See, e.g., 1977 House Hearings, supra note 5, at 46, 88-89; 1967 Senate Hearings, supra note 21, at 37. (Statement of Secretary of Labor Wirtz).

44. See generally Kovarsky \& Kovarsky, Economic, Medical and Legal Aspects of the Age Discrimination Laws in Employment, 27 VAND. L. REv. 839, 848-66 (1974).

45. See Smith v. Farah Mfg. Co., 650 F.2d 64, 67 (5th Cir. 1981) (age discrimination is qualitatively different from race or sex discrimination); Note, The Age Discrimination in Employment Act of 1967, 90 HaRv. L. Rev. 380, 384 (1976).

46. Special Committee on Aging, 93Ro Cong., Ist Sess., Improving the Age DiscrimINATION LAW iii (1973) (working paper). 
particular business."47 Further, an einployer can defend against a charge of age discrimination if "the differentiation is based on reasonable factors other than age." 48 Finally, an employer can "discharge or otherwise discipline an individual for good cause." 49 All of these express defenses embody concepts developed under other discrimination statutes. 50

In most situations, ${ }^{51}$ a cost-based discharge defense should be characterized as a discharge for cause. ${ }^{52}$ Characterization of the cost defense as discharge for cause allows the court to focus on what is actually occurring in the alleged discrimination. An einployer who has discharged a worker because he is too costly may not legitimately advance a defense based on high wages and benefits alone; whether or not an

47. 29 U.S.C. $\S 623(f)(1)(1976)$.

48. Id. For an analysis of the scope of this defense, see text accompanying notes 51-64 infra.

49. 29 U.S.C. § 623(f)(3)(Supp. IV 1980).

50. Similar defenses are provided for in Title VII of the Civil Rights Act of 1964.42 U.S.C. $\S 2000$ e -2(h) (1976). Title VII does not, however, have a discharge for cause provision. Nonetheless, because of the similarities between the Act and Title VII, courts have routinely applied Title VII interpretation and concepts to problems of age discrimination. See, eg., Hodgson v. First Fed. Sav. \& Loan Ass'n., 455 F.2d 818 (5th Cir. 1972) (applying test for a prima facie case under Title VII to age discrimination). The similarity in the language of the two statutes often justifies the use of one to interpret the other. The statutory-construction doctrine of in pari materia usually applies because courts recognize that "a legislative body generally uses a particular word with a consistent meaning in a given context." Erlenbaugh v. United States, 409 U.S. 239, 243 (1972). Thus, two statutes with similar language that cover the same general subject can be construed in pari materia, and language interpreted in one way may be used to construe identical language in the other. Id. at 243-44. There are, however, important differences between the two statutory sclemes that should act to prevent automatic application of Title VII concepts to age discrimination. See Note, supra note 45 . If a situation arising under one act has no analogy under the other act, then the reasons for applying in pari materia no longer exist. See 409 U.S. at 243-44. Because the cost defense in age discrimination is one of these situations, see text accompanying notes 43-45 supra, the Act itself must be carefully scrutinized.

51. In the hiring situation, the cost defense presents unique problems. See notes 65-85 infra and accompanying text. The "discharge for cause" characterization is also inappropriate where the employer innst discharge one of two workers who are both doing all that is required of thein. To take one example, if both A and B work on an assembly line and do all that is required of them, it is difficult for an employer who is forced to fire one of them to argue that he is discharging A for cause. Because the reason for disclarge is the employer's economic situation, rather than performance, this firing would be better labeled as based on "reasonable factors other than age." See 29 U.S.C. § 623(f)(1) (1976).

52. 29 U.S.C. § 623(f)(3) (Supp. IV 1980). See text accompanying notes $47-49$ supra for the relevant portions of the text of section 623(f).

The cost defense has also been cliaracterized as if it were a "reasonable factor other than age.” E.g., Mastie v. Great Lakes Steel Corp., 424 F. Supp. 1299, 1316 (E.D. Micl. 1976); Note, supra note 36, at 570. In fact, the two possible characterizations have been used interchangeably. See Bittar v. Air Canada, 10 Fair Empl. Prac. Cas. (BNA) 1136, 1137 (S.D. Fla. 1974) ("good cause" analysis), aff d, 512 F.2d 582, 583 (5th Cir. 1975) ("reasonable factors" other than age); Note, supra note 36, at $570 \mathrm{n} .24$. The exact characterization sliould not inake any difference in the ultimate outcome of the case since the eniployer bears the burden of proof for all defenses. See 29 C.F.R. $\S 860.103(\mathrm{e})(1980)$. 
employee costs too much depends directly on his performance..$^{53}$ Therefore, to discharge based on cost is, in effect, to discharge for unsatisfactory performance, ${ }^{54}$ whether or not such performance is measured relative to other employees. 55

There is considerable evidence that Congress intended to allow an employer to consider costs im choosing between employees. The employer could therefore discharge his most costly employees, those with the lowest output per dollar, ${ }^{56}$ for cause. Of the numerous anti-discrimination statutes, only the Act contains an express defense based on discharge for cause. Congress realized that at some point an aging employee's performance will decline and that at that point, the employer should be allowed to discharge the employee. ${ }^{57}$ This is not a harsh result. One expert, im explaining the workings of the Act, testified that the provision allowing discharge for cause simply shifts the onus of forced retirement from those who are arbitrarily retired because they have reached a certaim chronological age to those who are no longer able to perform because of the actual effects of physical aging. ${ }^{58}$ Only a retirement system based on performance is consistent with the Act's stated purpose of "proinot[ing] employment of older persons based on their ability rather than age." 59

An examination of the exception to the Act for retiresnent of tenured professors provides further evidence that Congress intended to allow employers to discharge the most costly employees for cause.

53. See notes $36-42$ supra and accompanying text.

54. See generally Note, supra note 36 , at 570 n.24. Arguably a performance discharge might be characterized as a discharge for a reasonable factor other than age. The note, however, citing ADEA Interpretations, 29 C.F.R. $\$ 860.130(f)$ (1977), posits that the "reasonable factors' exception is meant to cover a termination resulting from criteria or measurements that are applied to all employees and prompted by considerations unrelated to one imdividual's changing performance level." Id. Thus, an ability-related performance discharge is not a discharge for a reasonable factor other than age under the Act.

55. Most discharges for poor performance are based on a comparison of the performance of the discharged worker to that of other workers. There are, however, situations in which this is not the case. For example, if the employer has set some minimum standard for output and a worker fails to meet that standard, the employer may discharge the worker without regard to any other worker's performance.

56. E.g., Donnelly v. Exxon Research \& Eng'r Co., 12 Fair Empl. Prac. Cas. (BNA) 417, 420 (D.N.J. 1974) (the employer identified the most costly employees as those who failed to produce at least 75\% of their wages), affd mem, 521 F.2d 1398 (3rd Cir. 1975). For a critique of this method of evaluation, see notes 118-37 infra and accompanying text.

57. E.g., 1967 Senate Hearings, supra note 21, at 37 (statement of Secretary of Labor) (arbitrary age discrimination is prohibited, but once the aging process catches up with the employee and his performance falls "below the break-even poimt," the employer is justified im making a decision based on economics).

58. 1977 House Hearings, supra note 5, at 141 (remarks of Dr. Marc Rosenblum).

59. 29 U.S.C. $\$ 621(b)$ (1976). 
Section 631 (d $)^{60}$ allows an institution of higher education to enforce a program of compulsory retirement at age sixty-five. ${ }^{61}$ The legislative history indicates that Congress was concerned with the burden on universities that were being forced to retain costly tenured professors until age seventy, and that Congress was aware that "although it is theoretically possible to discharge tenured faculty for cause, the difficulty of objectively evaluating the performance of such employee[s] inakes such good cause discharges difficult." 62 Congress's concern for this difficulty implies that in other cases, in which performance is nore amenable to evaluation, ${ }^{63}$ the more costly employees may be terminated for cause when their performance does not justify their higher salaries. ${ }^{64}$

\section{Section 623(f)(2), An Express Exception, As Evidence of Congressional Intent.}

The existence of an express exception to the Act for the one situation in which Congress thought that cost is unrelated to performance is evidence that in all other situations in which cost is directly related to

60. 29 U.S.C. $\$ 631$ (d) (Supp. IV 1980). Section 631(d) provides in part: "Nothing in this chapter shall be construed to prohibit coinpulsory retirement of any employee who has attained 65 years of age . . . and who is serving under a contract of unlimited tenure . . at an institution of higher education ...."

61. Normally, persons up to age 70 are protected from mandatory retirement. See 29 U.S.C. $\S 631$ (a) (Supp. IV 1980).

62. S. REP. No. 493, 95th Cong., 1st Sess. 9 (1977).

63. There may be other situations in which performance cannot be readily evaluated. For example, it would be difficult to compare the performance of two supervisors in different, unrelated departments. Perhaps an analogy could be drawn to "bona fide occupational qualification" (see 29 U.S.C. §623(f)(1) (1976)) cases, in which the employer may use the forbidden classification if there is no other way to isolate the persons with the unwanted characteristic. See, e.g., Weeks v. Southern Bell Tel. \& Tel. Co., 408 F.2d 228, 235 (5th Cir. 1969). Applying this approach, if the employer demonstrates that he cannot objectively evaluate the employee's performance, the employer may use absolute costs as a basis for decision.

The existence of the narrowly drawn exception for tenured professors, however, tends to indicate that Congress believed that rehief was warranted ouly with respect to tenured professors. In all other cases, an evaluation was apparently considered possible, and absent evidence of differences in performance the employer's claim that one employee is more expensive than another must be disregarded.

64. See 1977 House Hearings, supra note 5, at 46 (remarks of Rep. Pepper, sponsor of the legislation) (procedures for weeding out incompetent employees); id. at 141-42 (Remarks of Dr. Marc Rosenblum) ("Good cause" may justify discharging employees who become less competent. It would not be an unreasonable burden to require employers to use performance, rather than age, because management "should continually be reviewing their work force as a part of sound management policy, and workers imcapable of performing their tasks properly should be separated"). See, e.g., Dounelly v. Exxon Research Eng'r Co., 12 Fair Empl. Prac. Cas. (BNA) 417, 421-22 (D.N.J. 1974). See text accompanying notes 127-28 supra for an analysis of the situation in which performance remains constant, but raises related to length of service cause the older employee to become more expensive than a younger, newer employee. 
performance, Congress intended to permit employers to utilize the cost defense. Section $623(f)(2)$ provides:

(f) It shall not be unlawful for an employer, employment agency, or labor organization ...

(2) to observe the terms of a bona fide semiority system or any bona fide employee benefit plan such as a retirement, pension, or insurance plan, which is not a subterfuge to evade the purpose of this chapter, except that no such employee benefit plan shall excuse the failure to hire any individual . . . 65

Statements froin various Congressinen and experts, ${ }^{66}$ including Senator Javits, the Act's principal sponsor, ${ }^{67}$ indicate that this provision was intended to allow employers to hire older workers without having to mcur the extra expenses necessary to provide them with pension and benefit programs equal to those of the younger workers. Thus, an employer who hires a young worker rather than one im the protected class cannot claim that his hiring decision was based on the cost differential between benefit programs because he is not obligated to provide equal benefits to the older worker.

1. Motivation for the Exception. One issue that arises is whether Congress intended the exception to eliminate an otherwise valid cost defense, or merely sought to remove an economic burden from employers complying with the Act. A review of the legislative history answers this question and refiects Congress's attitude toward the notion of a general cost defense.

Senator Javits's numerous stateinents in the legislative history about the cost defense are entitled to great weight im defining Congress's imtent. ${ }^{68}$ Most of his statenents regarding versions of the bill that did not contam a provision similar to section 623(f)(2) indicate that he thought that employers could not assert cost as a general defense in making hiring choices. For example, he stated:

[The administration's bill] does not provide any flexibility in the amount of pension benefits payable to older workers depending on their age when hired, and thus may actually encourage employers, faced with the necessity of paying greatly increased premiums, to

65. 29 U.S.C. $\S 623(f)(2)$ (Supp. IV 1980).

66. E.g., 1977 House Hearings, supra note 5, at 19 (remarks of Rep. Cohen), 114 (remarks of Dr. Marc Rosenblum, research scientist at the Center on Work \& Aging, American Institutes for Research); H.R. REP. No. 527, 95th Cong., 1st Sess. 26-27 (1977) (remarks of Rep. Weiss).

67. 1967 Senate Hearings, supra note 21, at 24-27 (remarks of Senator Javits) (The employer must be given some flexibility or else he will be forced to "look for excuses" not to hire the older workers).

68. See, e.g., Federal Energy Admin. v. Algonquim SNG, Inc., 426 U.S. 548, 564 (1976) (a statement by one of the legislation's sponsors should be accorded substantial weight in interpreting the statute). 
look for excuses not to hire older workers when they might have hired them under a law granting thein a degree of flexibility with respect to such matters. ${ }^{69}$

If cost alone were a legitimate defense in the hiring situation, no additional excuse would be needed. Therefore, the einployer would not need to "look for excuses not to hire older workers." Senator Javits beheved that absent the exception employers would be forced to hire older workers and pay the higher costs unless they could identify some other reason to avoid hiring the older worker. To prevent circumvention of the Act by feigned excuses, and to avoid imposing a heavy cost burden on employers to comply with the Act, Senator Javits introduced the amendment that eventually becaine section $623(\mathrm{f})(2) .^{70}$

The testimony of a representative from the United States Chamber of Commerce supports the position that cost is not a general defense. Speaking in support of section 623(f)(2), he stated, "if you saddle [the older worker] with the fact that he is going to cost the einployer $\$ 240$ a year [estimated differential in pension costs], nore than likely the ennployer will find another reason for not giving him employment."71 Thus, the reprcsentative of the business community beheved that cost alone would not be a defense unless the express exception were included in the statute. ${ }^{72}$

Some members of Congress, however, would have allowed cost to be a defense under the Act. In a rather clear statement of intent, Senator Smathers, a co-sponsor of the bill stated:

[I] $f$ the bill is interpreted to require employers to hire older workers and to provide the same fringe benefits for them as are provided for younger workers, regardless of costs, they would be given a handy excuse for refusing to hire older workers. They would be able to argue, with considerable justification, that their refusal to hire older workers is not due to arbitrary discrimination based upon age but instead is due to increased fringe benefit costs. ${ }^{73}$

Although Senator Smathers made some statements that cast doubt on

69. 1967 Senate Hearings, supra note 21, at 27 (emphasis added).

70. See, id.

71. 1967 House Hearings, supra note 42, at 70.

72. Other statements support this interpretation. Rep. Cohen, for example, spoke in favor of section $623(f)(2)$ and stated that:

[i]n order to avoid placing undue hardship on employees, it was the intent of Congress [im passing section 623(f)(2)] to permit the hiring of older workers without requiring that they be fully included in company employee benefit plans. This exemption was designed to encourage the hiring of older workers without bankrupting pension plans.

1977 House Hearings, supra note 5, at 21. Surely, if cost were a defense, there would be no danger that a rational employer would continue to hire older workers and pay them equal benefits to the poimt of bankruptimg his pension plan.

73. 1967 Senate Hearings, supra note 21 , at 30. 
his position, ${ }^{74}$ he apparently thought that an employer would always be justified in hiring a younger, less expensive applicant rather than an older, more expensive one.

Thus, there was arguably a sharp conflict between the sponsors over whether a simple comparison of costs would have been a justifiable defense before the enactment of section 623(f)(2). The most persuasive position, however, is that when the costs to be compared in the hiring decision are based directly on the age of the applicant, as are pension and benefit costs, ${ }^{75}$ cost is not a permissible defense. An examination of how the conflicting position works in practice supports this position. Assuming that pension and benefit costs mcrease sharply at age fifty, ${ }^{76}$ before the exception was added, an employer who offered pension benefits to his workers could have cliosen the applicant under fifty, rather than the equally qualified applicant over fifty, in every instance. ${ }^{77}$ The older worker would have been hired only when the employer voluntarily decided to pay the higher costs. Thus, the Act would have been reduced to a permissive rather than a mandatory statute, and older workers "protected" by the Act would have been forced to rely totally on the generosity of employers. This result was probably not the intent of Congress, because the legislative history. indicates that Congress recognized that cost, not malice towards the aged, is the cause of most age discrimination. ${ }^{78}$ Unless Congress expected employers to change voluntarily their practices, it would not have permitted them to nake employment decisions based on differences in pension and benefits before the exception was added.

74. For example, Senator Smathers insisted that the section that ultimately became section 623(f)(2) was needed to be fair to the employer. Id. This seems somewhat inconsistent with the position that the employer could use cost as a defense, because if the latter were true any burden assumed by the employer would be voluntary.

75. This situation would technically be labeled a disparate impact violation; cost, rather than the age of the applicant, is the factor being considered, but when cost is directly linked to age the classification has a direct and predictable effect on the protected group. The cost consideration has a disparate impact in that the protected group is systematically excluded. See Griggs v. Duke Power Co., 401 U.S. 424, 432-33 (1971). The next step would be for the employer to justify the classification as based on "reasonable factors other than age." 29 U.S.C. $§ 623(f)(1)(1976)$. This returns the analysis to the original question of whether cost alone was intended to be a permissible justification.

76. The congressional hearings did not contain hard data on the age at which the pension costs would increase. A direct correlation between age and costs was assumed. See generally Secretary's Report, supra note 3, at 40-51.

77. This assumes, of course, that the employer offered a pension benefit plan.

78. See, e.g., 1967 Senate Hearings, supra note 21, at 34 (statement of Senator Murphy) ("einployer discrimination results to a great extent froin employer misconceptious about the performance of older workers and the relative cost to the firm of hiring older rather than younger workers"). See text accompanying notes 33-35, supra. 
2. Effect of the Narrowly Drawn Cost Exception. Significant insights into the status of the cost defense in other contexts can be gained by determining why Congress chose to authorize expressly a cost defense only in the very narrow area of age-based benefits in the hiring situation. ${ }^{79}$ The legislative history is not, however, very helpful. ${ }^{80}$ The reasoning behind Congress's decision to include a cost defense solely in section 623(f)(2) can be gleaned only from a comparison of the operation of cost differentials in the hiring context, to which the exception applies, and the discharge context, in which no exception was necessary. ${ }^{81}$

In most situations the employer can make a decision based on comparative ability, because he can balance ability against cost and determine the relative inerits of each employee. For example, if an older worker's performance declines because of age-related physical deterioration to the poimt at which he becoines inore expensive, in terms of productivity per dollar, than a younger, less experienced but less well paid employee, the employer is justified in releasing the older worker. ${ }^{82}$ In this situation the Act functions sinoothly, because differentials in individual performance control the choice. In the hiring situation, however, the Act does not function as well. For example, if two workers of approximately equal ability apply for a position, but one, because of his age, will cost the employer more for pension benefits, the employer will probably choose the cheaper, younger employee. The employer knows that in the hiring context he can only make rough judgments of the employees' relative performance, based on their performance for other employers. Therefore, the einployer is likely to give undue weight to cost, thereby favoring the younger employee. Section 623(f)(2) remedies this situation by allowing the employer to equalize the costs, shifting the focus again to a direct comparison of individual abilities.

Congress apparently believed that in all other situations, including the discharge example discussed above, a comparison of cost to ability

79. That this is the only exception is reason in itself to argue that no other cost defense was intended. See note 42 supra.

80. The discussion surrounding section $623(\mathrm{f})(2)$ centered inainly on the consequences of failing to enact it. See text accompanying notes 68-78 supra. There was no comprehensive discussion about why other cost exceptions shonld not be permitted.

81. Courts often look to the purpose of a statute as a guide since differing interpretations of the statute may result in very different practical effects. Clear analysis of purpose may override even an express statement of legislative intent by the bill's sponsor. See, e.g., Chrysler Corp. v. Brown, 441 U.S. 281, 311-12 (1979).

82. For a complete discussion of seniority-based cost differences see text, section II B infra. 
would not unfairly disadvantage the older worker. ${ }^{83}$ The legislative history emphasizes the importance of individual performance assessments ${ }^{84}$ and contains repeated statenents that employers are not required to retain unqualified enployees. ${ }^{85}$ Congress believed that no broader cost exception was necessary because cost was a direct factor im the performance equation, and a coinparison of wages paid for work produced would not unfairly discriminate against older workers.

\section{Applying The Cost Defense to Discharges Of Workers Protected By The Act}

\section{A. Availability of the Cost Defense in Discharge Situations.}

There are several situations in which an employer might advance a cost-related defense after discharging a person protected by the Act. Most of these situations raise no serious problems. For example, it would be inconsistent with the goals of the Act to allow an employer, forced to discharge one of several employees, to discharge the einployee who had the least projected long-range potential with the company. ${ }^{86}$ Nor may an employer discharge an einployee who is unqualified to perform a new aspect of an expanded job classification if the younger employee who would replace him is also unqualified and would need comparable training. ${ }^{87}$ The inost difficult case arises when

83. Such a comparison could, however, penalize older workers who have been given seniority raises. See notes 118-42 infra and accompanying text.

84. See notes $43-46$ supra and accompanying text.

85. See notes 47-55 supra and accompanying text.

86. See, e.g., Hays v. Republic Steel Corp., 12 Fair Empl. Prac. Cas. (BNA) 1640, 1648 (N.D. Ala. 1974) (long-range potential to the company may not be used as a justification; otherwise, a younger person could always be preferred over an older person with equal ability) rev'd in part on other grounds, 531 F.2d 1307 (5th Cir. 1976).

87. E.g., LaChapelle v. Owens-Illinois, Inc., 14 Fair Empl. Prac. Cas. (BNA) 737 (N.D. Ga. 1976) (consent judgment) (a 57 year old employee discharged because he was not qualified to perform the duties of his new job classification was replaced with a 27 year old employee who was promoted and given training).

As a general rule, an employer may not use age as a factor in deciding who is to receive training. Coates v. National Cash Register Co., 433 F. Supp. 655, 661 (W.D. Va. 1977). A more difficult problem is whether an employer may consider expected return when deciding who is to receive long and costly training. The Department of Labor allows einployers to discriminate based on age in choosing persons for bona fide apprenticeship programs. 1977 Senate Hearings on S. 1784, supra note 24, at 23; 29 C.F.R. $\$ 860.106$ (1980). In hearings on the Act, Senator Randolph asked former Secretary of Labor Willard Wirtz whether an airline which invests upwards of $\$ 250,000$ to train a pilot over a period of three years would be required by the Act to hire a person who is 45 years old even though the FAA rules force cominercial pilots to retire at age 60 . The essence of the question was whether an employer could consider age as a factor in assessing the potential for recouping the costs incurred in training an employee. Secretary Wirtz, after quoting $\S 623(f)(1)$ of the Act, replied: "I would think where there is that inuch training requirement, that that would be a legitimate factor, that you would weigh the period of the usefulness of that person 
an employer discharges some employees because of poor economic conditions and follows a policy of dismissing the most highly paid employees. This policy has, a disparate impact on the employer's older workers ${ }^{88}$ and sharply presents the mechanics of the cost defense in the discharge situation.

As a prerequisite to any charge of age discrimination, the employee must establish a prima facie case. Several courts liave held that the McDonnell Douglas Corp. v. Green ${ }^{89}$ standard, which articulates the elements of a prima facie case under Title VII, applies to the Act, but most courts apply a more flexible approach and use $M c$ Donnell Douglas merely as a guide. ${ }^{90}$ Notwithstanding the need for flexibility, some generalizations can be made about particular types of complaimts.

When an employee has been terminated after an individual evaluation, his prima facie case consists of a showing that (1) he was in the protected category; (2) his performance was satisfactory; ${ }^{91}$ (3) he was

against the period of the training that was required taking full account of the cost factors and human factors." 1967 Senate Hearings, supra note 21, at 49. Thus, if the age of the employee were to prevent the employer from recovering an initial cost outlay for training, the employer could discriminate against the person either in hiring or in placement into a training program.

This raises the problem of how to calculate the employee's longevity. In the airline situation, the FAA's age 60 rule provides a yardstick. In other situations, the employer could use age 70 as a cutoff because persons over 70 are not protected by the Act. 29 U.S.C. $\$ 631$ (a) (Supp. IV 1980). Should an employer wish to establish a lower cutoff, however, he would bear the burden of proving that all or substantially all persons who reach that age are no longer able to perforin the job, or that some persons who reach that age are not able to perforin and it is inpossible or impractical to screen out those persons in advance. Cf. Weeks v. Southern Bell Tel. \& Tel. Co., 408 F.2d 228, 235 (5th Cir. 1969) (by failing to estabhish that "all or substantially all women would be unable to perform safely and efficiently the duties of the job involved" defendant was precluded from relying on the "bona fide occupational qualification" exception).

The Secretary's statement sheds no light on whether an employer may seek to maximize profits by training the youngest people, or whether he may discriminate only as is necessary to prevent a loss. In most situations maximization of profits is not a legitimate justification. See notes 119-24 infra and accompanying text. Perhaps, however, this situation is unique, and an employer should be allowed to reccive a reasonable return on his investment. Arguably, a person too old to work the required number of years is not qualified.

88. See notes 100-17 infra and accompanying text.

89. 411 U.S. 792 (1973). The four-prong McDonnell Douglas standard defines the prima facie burden which a Title VII plaintiff bears. He must show that: 1) he belongs to the protected class; 2 ) he applied for and was qualified for a job for which the employer was seeking applicants; 3) he was rejected despite his qualifications; and 4) the position remained open and the einployer continued to seek applications from persons with similar qualifications after rejecting him. Id. at 802.

90. E.g., Marshall v. Goodyear Tire \& Rubber Co., 554 F.2d 730, 735-36 (5th Cir. 1977).

91. At least one court has held that the einployee need not prove he was performing satisfactory work if his prima facie case otherwise allows an inference of age discrimination. See id. Cf. Wilson v. Sealtest Foods Div. of Kraftco Corp., 501 F.2d 84, 86 (5th Cir. 1974) (the employee must show only that he was doing "apparently satisfactory work"). The Marshall decision is correct in its emphasis on a review of the facts of each case, and this emphasis is not inconsistent with requiring some showing of satisfactory performance. The original rationale for requiring a 
discharged; and (4) he was replaced by a person outside the protected group. ${ }^{92}$ These elements vary if the employee is among a group which is discharged during an economic slowdown and whose jobs are discontinued or left vacant. Consistent with the McDonnell Douglas rationale that the requireinent of a prima facie case is intended to eliminate the inost likely nondiscriminatory reasons for discharge, ${ }^{93}$ an employee discharged after his job is discontimued must establish that he was qualified to assume another position. ${ }^{94}$

Solne employees can establish a prima facie case by proving the use of an unlawful employment practice. For example, it is possible to use statistics to establish a pattern or practice violation. In Schulz $v$. Hickok Manufacturing Co., ${ }^{95}$ the plaimtiff demonstrated that after a wave of discharges, the average age in the job category at issue fell from 53.39 to $40.75 .9^{96}$ An employee can also estabhish a prima facie case by showing that a seemingly neutral classification factor has a disparate impact on the protected class. ${ }^{97}$ In the context of the cost defense, this is inost likely to occur when the einployer discharges his most costly einployees, then argues that cost, not age, was the deciding

plaintiff to prove a prima facie case was to eliminate cases founded upon the most common reasons for refusing to hire or for discharging: lack of qualifications; lack of openings; poor performance; or a need to lay off workers. See McDonnell Douglas Corp. v. Green, 411 U.S. 792 (1973); Loeb v. Textron Inc., 600 F.2d 1003 (1st Cir. 1979). Because a frequent cause for discharge is poor performance, the plaintiff should have to prove that his performance has been satisfactory or has not declined substantially. He should not, however, be required to prove his performance surpassed those who were retained; proving that he is more qualified than others is not part of his prima facie case.

92. There is also soine dispute over whether an employee must prove he was replaced by a person outside the protected group. Compare Harpring v. Continental Oil Co., 628 F.2d 406, 408 (5th Cir. 1980) (replacement is a necessary element), cert. denied, 102 S. Ct. 100 (1981) with Bonhain v. Dresser Indus., 569 F.2d 187, 195 (3rd Cir.) (replacement is not necessarily an element), cert. denied, 439 U.S. 821 (1978). This may depend on the facts of the case: replacement should not be required in a situation $\mathrm{m}$ which the job is eliminated or left vacant for economic reasons.

93. See note 91 supra.

94. Williams v. General Motors Corp., 656 F.2d 120,129 (5th Cir. 1981), cert. denied, 102 S.Ct. 1439 (1982). Of course, if the reason the employee is not qualified is that training was offered in a discriminatory fashion, the analysis would differ. See Coates v. National Cash Register Co., 433 F. Supp. 655, 661 (W.D. Va. 1977).

95. 358 F. Supp. 1208 (N.D. Ga. 1973).

96. Id. at 1213. There is, however, a danger in relying too much on statistics in age discrimination cases because of the natural tendency to replace retired workers with persons younger than those retiring. $C f$. Lindsey v. Southwestern Bell Tel. Co., 546 F.2d 1123 (5th Cir. 1977).

97. See, eg., Griggs v. Duke Power Co., 401 U.S. 424 (1971) (testing requirements lad a disparate impact on blacks); Spurlock v. United Airlines, Inc., 475 F.2d 216 (10th Cir. 1972) (plaintiff alleged that a college degree requirenent for pilots had a disparate impact on blacks, but the court held the requirement valid because it was job-related). Although it is not entirely clear that Griggs can be apphed to age discrimination, the Secretary of Labor's interpretative guidelines have consistently indicated that disparate impact analysis may be used. E.g., 29 C.F.R. 860.103(f)(1) (1981) (physical fitness standards). 
factor. Provided there is a substantial showing that the most costly employees were the oldest, ${ }^{98}$ a disparate impact case would probably be estabhished.

Once the employee has made out his prima facie case, the employer can either deny or attempt to justify the alleged discrimination. Assertion of the cost defense is a demal of discrimination based on age. The argument is that the employee was not earning his salary. In terms of the express defenses available under the Act, ${ }^{99}$ the employer usually claims that the discharge was for cause under section 623(f)(3). In most of these cases, the employer conducted evaluations and decided which employees were the most expendable. In response, the employee often argues that age was a factor in the evaluation, ${ }^{100}$ or that the evaluation was a pretext for discrimination based on age. ${ }^{101}$ If the evaluations fairly measured performance, ${ }^{102}$ and if the employer used the evaluations to decide which employees were most expensive in the relative sense, the courts have usually affirmed the discharge. ${ }^{103}$

In Donnelly v. Exxon Research \& Engineering Co. ${ }^{104}$ Exxon had a policy of discharging persons who were not producing at least seventyfive percent of the value of their wages. ${ }^{105}$ The plaintiff challenged the practice, arguing that because older workers were paid more because of

98. See note 25 supra.

99. 29 U.S.C. $\$ 623(f)$ (Supp. IV 1980). See text accompanying notes $47-49$ supra for the relevant portions of section $623(\mathrm{f})$.

100. This assertion brings the reliability of the evaluation into question. Assuming that costbased discliarges liave a disparate impact on older employees, see note 35 supra and accompanying text, the employer must prove the propriety of the evaluation. See Griggs v. Duke Power Co., 401 U.S. 424 (1971). The courts have tended to be flexible in uploolding particular evaluation procedures. The primary objective is to decide whether age was used adversely. Gill v. Union Carbide Corp., 368 F. Supp. 364, 369 (E.D. Tenn. 1973). To use the language of the regulations promulgated under the Act, age may not be the "dcterinining factor" in the decision to terminate. 29 C.F.R. $\$ 860.103$ (c) (1980). See Hays v. Republic Steel Corp., 12 Fair Empl. Prac. Cas. (BNA) 1640,1648 (N.D. Ala 1974) (length of time to retirement was a detcrmining factor in terminating plaintiffs), affd in part and rev'd in part on other grounds, 531 F.2d 1307 (5th Cir. 1976).

Generally, a performance evaluation based on objective factors will be upheld absent a sliowing of pretext or discriminatory application. For example, in Marsliall v. Hills Bros., 432 F. Supp. 1320, 1324 (N.D. Cal. 1977), the following evaluation factors were upheld:

(a) ability to perform present functions; (b) ability to adjust to the necessary clianges in the company's operation; (c) effectiveness on the job, with particular focus on supervisory competence and past achievement in the context of Hills Brothers' present problems; (d) versatility, with consideration whether the imdividual had the ability to move into another area of operations; (e) uniqueness, considering whether the individual lrad some special skills which were necessary to a particular function; $(f)$ inotivation and initiative; $(\mathrm{g})$ availability of replacements.

101. See notes $133-42$ infra and accompanying text.

102. See note 100 supra.

103. See cases cited in notes 104,108 , and 114 infra.

104. 12 Fair Empl. Prac. Cas. (BNA) 417 (D.N.J. 1974).

105. Id. at 420 . 
semiority raises, they were more likely to be termmated. ${ }^{106}$ The court rejected this argument, apparently failing to realize that an employee who was paid more because of semority raises would be terminated before a younger, less expensive employee with equal ability.107 Notwithstanding the overbroad reach of the decision, the court's recogmition that relative cost is a function of performance and that the least cost-effective employees can be terminated regardless of age is significant.

Similarly, im Mastie v. Great Lakes Steel Corp. ${ }^{108}$ the court upheld the discharge of two employees who alleged that they were terminated because of age-related costs. ${ }^{109}$ Although the court held that an employer can always discharge its least desirable employees after an objective evaluation, ${ }^{110}$ the case in fact involved employees who were regarded as too costly to retain at their present salary level. ${ }^{111}$ In spite of the correct result reached in the case, ${ }^{112}$ the court implied in dicta that absolute costs, rather than costs relative to performance, could control a discharge decision. ${ }^{113}$

Consistent with the view that cost is meaningless without an evaluation of performance, the court in Schulz v. Hickok Manufacturing Co. ${ }^{114}$ held that when the evidence establishes that the discharged employee's performance was better than that of the retained employees, the cost-based discharge is unlawful. ${ }^{15}$ The court reviewed the einployer's findings regarding the output of each employee to decide

106. Id. at 421-22.

107. The evidence in the case indicated that the plaintif's performance was completely unsatisfactory. He was given numerous warnings in conferences called specifically to discuss his performance. Id. at 420 . Thus, the court probably did not perceive the situation as one in which there were younger, less expensive employees of equal ability who were retained. The court recognized the problem when it stated:

It would be nnlawful . . . if an einployer were to fire an older worker doing satisfactory work who, because of his seniority received a certain salary because the employer wished to replace him with someone else who would do no better work but who, as a younger man with less seniority, would do the work for less.

Id. at 421-22 (emphasis added). For a proposed solution to the problem of the effect of seniority on wages, see notes 118-32 infra and accompanying text.

108. 424 F. Supp. 1299 (E.D. Mich. 1976).

109. Id. at 1305 .

110. Id. at 1316, 1319.

111. The employees were offered other positions at a reduced salary. Id. at 1304.

112. The assumption is that the performance evaluations indicated that the employees were in fact the most costly relative to their performance.

113. 424 F. Supp. at 1319. The court relied on statements of Senator Smathers in the legislative history indicating that simple absolute-cost distinctions could control the hirmg decision. Id. at 1318. But, as noted earher, hiring is a different situation because performance does not enter into the equation. See notes $82-85$ supra and accompanying text.

114. 358 F. Supp. 1208 (N.D. Ga. 1973).

115. Id. at 1216 . 
whether the employer's determination of the most efficient employees was correct. ${ }^{116}$

Although the rationales of the above cases differ, the cases are consistent with the Act's goal of forcing the employer to consider the performance of the individual employee. ${ }^{117}$ Further, they recognize that performance is a determining factor of cost. Based on these cases, an employer is within the bounds of the Act if he considers performance when discharging employees based on cost.

\section{B. Factoring Out Seniority-Based Cost Differences.}

If seniority plays some part in wage increases, then older workers will generally be paid inore ${ }^{118}$ than younger workers of equal ability. Therefore, if an employer must make discharges based on a comparison of wages to performance, older workers of equal ability will always be discharged first. Resolution of this problem depends on whether the Act protects the employee from a discharge arising from the age-related cost of a wage differential based on seniority. Several courts have held that such action is improper because it is based on a factor directly related to age. ${ }^{119}$ Furthermore, Congress went to great lengths in the Act to prohibit mandatory retirennent or discharges based on an arbitrarily determined age. ${ }^{120}$ If an employer could discharge an einployee using a cost defense when the wage differential is based on seiniority, he could evade the Act by giving each employee a nominal raise at the end of each year of service and then occasionally "retiring" the inost expensive-and oldest-employees. ${ }^{121}$

Although an employer may not discharge the inore expensive exnployee if the differential is based on seniority, in most situations wage differentials are the product of both inerit and seniority. ${ }^{122}$ Thus, ein-

116. See id. at 1215-16.

117. 29 U.S.C. \& 621(b) (1976).

118. See note 35 supra.

119. See, e.g., Marshall v. Arlene Knitwear, Inc., 454 F. Supp. 715 (E.D.N.Y. 1978) (factors directly related to age, such as expected future service, may not be considered); Donnelly v. Exxon Research \& Eng'r Co., 12 Fair Empl. Prac. Cas. (BNA) 417, $421-22$ (D.N.J. 1974), (dicta) (unlawful to fire senior employee doing satisfactory work and replace him with less expensive junior employee), modified mem., 608 F.2d 1369 (2d Cir. 1979).

120. See, e.g., 29 U.S.C. $\S 623($ ())(2) (Supp. IV 1980).

121. 29 U.S.C. $\S 631(\mathrm{c})(1)$ allows an enuployer to retire a bona fide executive. But, to prevent circumvention of the purposes of the Act, Congress required that the retired executive must have held the qualifying position for at least two years. This requirement prevents employers from transferring undesirable employees to executive positions and then retiring them immediately. H.R. REP. No. 950, 95th Cong., 2d Sess. 9 (1978).

122. See, e.g., Donnelly v. Exxon Research \& Eng'r Co., 12 Fair Empl. Prac. Cas. (BNA) 417, 419 (D.N.J. 1974). 
ployers need a method which factors out the seniority-based wages and compares only the relative performance of various employees. To illustrate, assume that employee $A$, age 50 , makes $\$ 50,000$ a year and produces $\$ 60,000$; employee $B$, age 35 , makes $\$ 45,000$ a year and produces $\$ 58,000$. The employees are close in ability, yet employee A, who is protected by the Act, is proportionately more expensive. Based on these facts, the employer should not be permitted to use cost as a justification for discharging employee $A$ because the wage differential must be based on semiority, ${ }^{123}$ a factor that may not be considered in a discharge. ${ }^{124}$

The facts do not disclose the amount of the salary differential based on seniority, but the salary differential is so much greater than the production differential that some portion must be based on seniority. Thus, the employer should not be able to argue that he has a pure merit system and that he should therefore be able to compare the cost/production differentials directly. Either the difference is based on age, a factor the employer must not consider, or the employer is paying the older employee more because he produces more. The proper solution is to require the employer to establish that the younger employee he seeks to retain is more qualified because he produces more. If this is done the employer would be justified in discharging the older, less productive worker even if he were paid the same as the younger worker. Thus, the older worker is not being penalized for seniority raises by this comparison, and the approach is consistent with the course Congress took in the context of age-related hiring costs. ${ }^{125}$ The approach allows the employer to compare ability as if a pure merit system existed 126 and to retain the most qualified employee, the one who produces the most relative to a salary uninflated by seniority raises.

In the above example, employee $A$ is the most productive, so he is the most qualified and may not be discharged because of cost. Even if the output for $A$ and $B$ were equal, the employer could not discharge $A$ based on a comparison of relative costs because $B$ is not more qualified than A. This approacli remedies the discriminatory situation discussed by the Donnelly court, in which the employer has two employees of

123. If wages were based purely on merit, the salaries would be directly proportional to output. There is, of course, the possibility that some other factor other than seniority might be involved. Provided the factor is not tied to age, the employer could probably establish that it would not violate the Act to nake decisions based on that factor.

124. See notes 118-19 supra and accompanying text.

125. See notes 79-85 supra and accompanying text.

126. If employees with the same output would be paid the same except for seniority any penalty for seniority is removed. 
equal ability but the younger one, with less seniority, is cheaper. ${ }^{127} \mathrm{Be}-$ cause the differential is due to age, the employer may not discharge the older, more expensive employee. Under the proposed analysis, once the older employee's performance falls below that of the younger employee, he becomes more expensive even if they are paid the same, and a cause discharge is permissible. ${ }^{128}$ It necessarily follows that the older employee is more expensive whenever his performance falls below that of the younger worker who is paid less.

The proposed analysis is an accurate, simple way to factor out the effect of raises based on seniority. Its major flaw is that it assumes that merit and seniority are the only factors considered in determining salary. This can be remedied, however, because the employer remains free to prove that any differential is not based on seniority. Implementation of this analysis might have the beneficial effect of discouraging automatic seniority-based raises that are not based on merit, and encouraging employers to look solely to ability, furthering the ultimate goals of the Act.

Critics 1might argue that the proposed analysis fails to allow for situations in which the employer is having severe financial probleins and cannot afford to retaim persons whose wages are inflated by seniority raises. If the employer is driven out of business by the high cost of wages, then all employees suffer. ${ }^{129}$ This seems to be crying wolf; the employer is required only to retain his most qualified workers. Sonve of the most qualified workers may have wages inflated by seniority raises, ${ }^{130}$ but the older workers must be performing at least at the level of the younger workers or they could be released under the proposed standard. The most burdensome situation is when older and younger employees have equal qualifications and the einployer is forced to retaim the older but more expensive employees, and must therefore pay the wages inflated by seniority. However, it is unlikely that this situation would occur. If the employer does suffer an unusual burden from seniority-based wage differences, and he can prove that the differential caused by seniority wages alone will drive him out of busmess, remedial action could be taken. ${ }^{131}$ Absent such a showing, mere economic

127. See note 107 supra.

128. This would simply be the situation in which there is no inflation in wages because of seniority. See notes 100-17 supra and accompanying text.

129. See Note, supra note 36 , at 586-87.

130. See, e.g., Suzuki, supra note 35 , at 73 (work experience is an important factor in seniority raises).

131. Perhaps the less-detrimental-alternative standard used under Title VII could be apphed in this narrow situation. See generally Robinson v. Lorillard Corp., 444 F.2d 791, 798 (4th Cir.) (application of standard in Title VII action), cert. dismissed, 404 U.S. 1006 (1971); cf., Note, supra 
hardship does not excuse a violation of the law. ${ }^{132}$

\section{The Employee's Option to Show Pretext.}

If the employer meets the burden of showing that the discharge was justified, the employee has the opportunity to show that the justification was a pretext for age discrimination. ${ }^{133}$ In several cases courts have looked beyond the employer's justification to determine the real reason for the action taken. The cases fall into two categories, either the employer's justification is a blatant pretext, or the testimg itself is unfair.

A clear example of a blatant pretext occurred in LaChapelle $v$. Owens-Illinois, Inc., 134 in which the plaimtiff was discharged after being judged unqualified to perform the expanded functions of his job. The evaluation was done fairly, but the employer violated the Act when he offered to traim the replacement without making the same offer to the plaintiff. ${ }^{35}$ Thus, the defense of lack of qualification was a mere pretext for age discrimination. Another example of pretext occurred in Marshall v. Arlene Knitwear, Inc., ${ }^{136}$ in which the employer atteinpted to discharge the oldest of his three designers by closing and then reopening his plant under a new name without the oldest designer. ${ }^{137}$ The employer tried to show that the other designers were more qualified, but the evidence was meager and contradictory. 138

In Schulz v. Hickok Manufacturing Co. ${ }^{139}$ the court looked beyond the employer's evidence that the plaintiff's performance was below that of his co-worker's to determine that the test was unfair. The employer had discharged Schulz based on subjective evaluations, statimg that his performance as a district inanager was unsatisfactory. The court considered the statistical evidence, mcluding Schulz's sales figures. It con-

note 36 , at 587-95 (the less-detrimental-alternative standard on a much broader scale). If this approach is used, perhaps the employees could be given the option of voluntarily forfeiting that portion of their wages attributable to seniority raises. Arguably, however, the forfeiture would violate 29 U.S.C. \$ 623(a)(3) (1976), which prohibits an enployer from reducing any wage to comply with the Act. However, such a practice would probably not be held to violate the Act. Note, supra note 36 , at 592 n.125.

132. See, e.g., EEOC v. Baltimore \& O. R.R., 632 F.2d 1107 (4th Cir. 1980), cert. denied, 102 S.Ct. 113 (1981).

133. See generally McDonnell Douglas Corp. v. Green, 411 U.S. 792, 804 (1973) (Title VII racial discrimination action). See cases cited in notes 134-42 infra.

134. 14 Fair Empl. Prac. Cas. (BNA) 737 (N.D. Ga. 1976) (consent judgment).

135. Id, at $739-40$.

136. 454 F. Supp. 715 (E.D.N.Y. 1978), modified mem, 608 F.2d 1369 (2d Cir. 1979).

137. Id. at 724-25.

138. Id. at $729-30$.

139. 358 F. Supp. 1208 (N.D. Ga. 1973). 
cluded that he was more effective than the retained district managers ${ }^{\mathbf{1 4 0}}$ and held that the subjective evaluation was invalid.141 Other courts have noted that sham tests or those that are administered in a discriminatory manner are invalid. ${ }^{142}$

\section{Conclusion}

The confusion in the courts regarding the status of the cost defense under the Age Discrimination in Employment Act of 1967 exists mainly because of a failure to consider the major purpose of the Actto encourage employers to consider an individual's ability, rather than his chronological age. For employers this means that the cost of an employee must be measured in terms of the einployee's record of performance. The Act's prohibitions are not violated if an employer identifies his most costly employees by using performance as a direct factor in computing cost, so long as age-related factors such as seniority raises are factored out. The Act was not intended to force employers to keep mcompetent persons on the payroll. Its objectives were to make performance, rather than an arbitrarily selected chronological age, the selection criterion, and to shift the onus of retirement from the chronologically aged to the plyysiologically aged. The message of the Act to employers is quite simple-consider ability, not age.

Terrence P. Collingsworth

140. Id. at 1215-16.

141. Id. at 1216.

142. See, e.g., Reed v. Shell Oil Co., 14 Fair Empl. Prac. Cas. (BNA) 875, 877 (S.D. Ohio 1977) (dicta), vacated mem, 582 F.2d 1280 (6th Cir. 1978). 